\title{
TEACHER'S MUSIC ACTIVITIES IN THE CLASSROOM AS A PREREQUISITE FOR IMPROVEMENT OF MUSIC EDUCATION
}

\author{
Asta Rauduvaitė \\ Yanran Li \\ Lithuanian University of Educational Sciences, Lithuania
}

\begin{abstract}
The relevance of the research is realized through the search for the music teacher's activities that help to improve the process of music education while fostering the learner's aesthetic and meaningful relationship to music. The object of the research is a music teacher's activity of teaching music in general education school. The aim of the research is to analyse the improvement opportunities of a music teacher's activity during music lessons in seventheighth grades in general education schools. The methods of the research include the analysis of scientific literature and documents of education; semi-structured interviews with music teachers; a written survey; quantitative and qualitative data analysis. According to the collected data, a variety of musical activities helps to develop learners' inborn musical abilities, provide a favourable learning environment with an opportunity to develop the learners' musicianship and presuppose their transferable skills. In this context, teachers' active and creative musical involvement helps the learner to experience more positive emotions. Such a personal involvement and cooperation serve as a major condition for the improvement of the teachers' musical activity. An inappropriate choice of the activities can lead to dissatisfaction and be the main reason for failure. The teachers' participation in musical activities could encompass a number of music modes, which could create a more attractive and productive activity in the lesson: a teacher - a performer - a listener - a facilitator - a leader.
\end{abstract}

Keywords: music education, music teacher, musical activities.

\section{Introduction}

Globalisation trends uniting Europe, as well as tendencies of social integration and harmonisation create new possibilities for the social development of individuals and school learners. A person's self-dependence, his/her moral maturity and multifaceted contemporary competence as a positive socialisation occupies a specific place in this context. Therefore, when setting educational goals, it is important to take into consideration all the factors, which may have influence on attaining them and maintaining the relation of the learners themselves with the familiar reality. In such a context, initial music education taught in an attractive activity may contribute to the development of learners' value-based attitudes, abilities, knowledge and understanding in the integral 
Rauduvaite \& Li, 2018. Teacher's Music Activities in the Classroom as a Prerequisite for Improvement of Music Education

process of education (General Curricula of Primary and Basic Education of Lithuania, 2009).

Nowadays, education is a prerequisite for an individual's success in life, whereas learning is acknowledged as a key factor in an individual's improvement. Learners of seventh-eighth grades face many challenges and opportunities, mainly due to the complex period that they experience. Adolescents face both physical and mental change. As a result, they cultivate a good manner of thinking and appreciation, by cause of a vital period which can absorb many new things (Strakšienè, 2009; Balčytis, 2012; Liu, 2012; Juvonen, Ruismaki, \& Lehtonen, 2012; Wang, 2012; Mantie, 2013; Yang, 2013; Mark \& Madera, 2014; Zhao, 2015; Rauduvaite, 2016; and others). Due to the increasing change in the society, music education needs to be advanced and reflect modern accomplishments, as well as it needs to enhance the aesthetic ability in the meantime. Therefore, it demonstrates a teacher's educational area which is an important part not only for the school learners' classes, but also affects adolescents' daily life. The promotion of the development of music education in the classroom is mainly based on the foundation of the most needed elements in the teaching process, by applying it to the classroom through the use of music activities, improving students' interests and music ability.

Teaching of music in ordinary school music activities has an indispensable position. Throughout the analysis, we discover that feedback is an important part of music activities, it can help teachers to complete a higher level of educational goals in the classroom. A music teacher's activity should have vivid and intuitive features in order to stimulate the learners' interests and enthusiasm in learning music, which is the key difference between the music discipline and other disciplines. Teachers should provide more chances for the learners, allow them to experience and create themselves. Providing a more convenient approach to achieve the ultimate goal of music education can intensify the capability of music comprehension. The problem of the research defines the question - music itself is of a creative nature; therefore, the relevance of the research is realised through the search of the kind of a music teacher's activity, which helps to improve the process of music education while fostering the learner's aesthetic and meaningful relationship to music.

The object of the research is a music teacher's activity of teaching music in general education school.

The aim of the research is to analyse the improvement opportunities of a music teacher's activity in music lessons in the seventh-eighth grades in general education schools.

The methods of the research: analysis of scientific literature and documents of education; semi-structured interviews with music teachers; a written survey; quantitative and qualitative data analysis. 


\section{Data collection and data analysis}

Semi-structured interviews with music teachers (15 music teachers participated in the research, 8 Lithuanian and 7 Chinese teachers) and a written survey compiled on the basis of D. Strakšiene's (2009) method were used in the research. The questionnaire survey (closed-ended questions) was compiled on the basis of theoretical conceptions and the modelling of a music teacher's activity. Two groups of students participated in the written survey - 60 Chinese and 40 Lithuanian future music teachers, who studied at the Lithuanian University of Educational Sciences. The analysis of qualitative data was applied in the transcription of texts and creation of categories (Žydžiūnaitè \& Sabaliauskas, 2017).

\section{Results}

During the research, it was it was important to highlight the significance of the goals of music education at the stage of basic education by asking future music teachers to rank the indicated goals from most to least important. It goes without saying that all the aforesaid goals are essential; therefore, it was not easy to define the order of their significance.

The order of the goals of music education was as follows: 1) theoretical knowledge about composers' life and work, knowledge of music genres, directions; 2) formation and development of the skills of of music work analysis; 3 ) critical evaluation of everyday music reality (music on the radio and visual recordings); 4) development of innate music ability (musical hearing, vocals, rhythm sensation, etc.); 5) formation and development of instrumental musicianship and singing skills; 6) emotional relation with a music work: admiration, incurred emotional experiences; 7) education of musical taste and proper value orientation; 8) theoretical knowledge about music terms and music expression means; 9) elements of independent authorial music creativity: an attempt to create songs, write music, and arrangement. According to the analysis, all participants cared more about the theoretical knowledge in the teaching process, as well as listening to and analysing music.

It is possible to claim that due to the consolidation of music computer technologies, particular features of music culture reflecting the surrounding environment are highlighted. The accoustic environment affects learners' lifestyle and their musicality, promotes a need for the exoerienced feelings, as well as relates the preriod of adolescence with tin-pan music sounds. Therefore, the development of the skills of listening to music and music making becomes a necessity in the changing society. It is important to develop as personality that has 
Rauduvaite \& Li, 2018. Teacher's Music Activities in the Classroom as a Prerequisite for Improvement of Music Education

acquired the skills of sound self-control and a feeling for the subtlety of music sounds.

Aiming to develop learners' abilities of listening to music and analysis of music works, it was important to highlight possible forms of their music activity in a music lesson. The future music teachers were asked to rank the music activities specified by the learners according to their importance. It goes without saying that all the forms of learners' activity while listening to music are important, yet it we were interested in the activities that were given priority. The ranks of the forms of the learners' activity while listening to music were as follows: 1) get acquainted with the music of a historical epoch (the biographies and most famous music works of composers of different epochs); 2) recognise the timbre of music instruments; 3) while listening to music, seek to experience maximum enjoyment; 4) recognise the most typical music genres and music forms; 5) associate playing music with other forms of artistic expression (write essays, draw); 6) argumentatively evaluate and compare music pieces that they listened to; 7) discuss emotional experiences induced by the intonation of music; 8) examine and evaluate the properties of a music piece (mood, form, contrast, tempo, dynamics, timbre, rhythm, etc.); 9) know notes and read uncomplicated scores (layering of voices, melodic, harmonic part or the like).

The ranks presented above allow claiming that the future music teachers envisaged the significance of a learner's personal relationship with a music work; yet it was also important to promote every learner to seek for the personal meaningfulness of a work while discussing the emotional experiences raised by music and properties of a music work. It is obvious that the latter activities were relevant for the education of future music teachers. According to the research conducted by S. H. M. Carvalho \& A. Scavardos (2014), music education should become a phenomenal means that would help to convert the connections between technologies and social, cultural and economic life, which affect the learners' personal maturity.

Aiming at disclosing the viewpoints on teaching methods in different parts of a music class, we revolved around the advantages and disadvantages that the teachers faced during the class work, as well as the counter measures they applied to improve the quality of the class work. Attempts were made to disclose the possibilities of applying a variety of techniques and means that would raise the learners' interest during a music class (Table 1).

Table 1 demonstrates the application of different techniques in music lessons by the future music teachers. The greatest number of the Chinese students disagreed with the usage of the method of "Literature, poetry and extract reading related to the listened piece", whereas $32 \%$ of the Chinese students said that they were uncertain about the "Learners' creative works, related to the listened music piece", which shows a lack of their creativity in teaching. The most popular 
method among the Chinese students was "Discussion of the most important details of the listened piano piece" receiving $72 \%$ of the votes, which means that most of them admitted the importance of using the piano in music classes. As far as the Lithuanian students are concerned, the table describes teaching techniques and approaches, which are peculiar to Lithuania. Only a few of them had any objections at all, the only teaching methods that the students disagreed with were "Literature, poetry and extract reading related to the listened piece" and "Discussion of the most important details of the listened piano piece" - both receiving $23 \%$ in total; $77 \%$ of the Lithuanian students had indicated that they liked "learners' creative works, related to the listened music piece"; they believed that learners' creative work should have a connection to listening to music.

Table 1 Teachers' attitudes towards teaching techniques and means (\%)

\begin{tabular}{|c|c|c|c|}
\hline Teaching techniques and means & Disagree & $\begin{array}{l}\text { Don't } \\
\text { know }\end{array}$ & $\begin{array}{l}\text { Completel } \\
\text { y agree }\end{array}$ \\
\hline \multirow{2}{*}{$\begin{array}{l}\text { Usage of various schemes, tables, posters and other } \\
\text { visual materials }\end{array}$} & * 17 & 13 & 70 \\
\hline & $* * 5$ & 12 & 83 \\
\hline \multirow{2}{*}{$\begin{array}{l}\text { Demonstrations of works of art while listening of a } \\
\text { music piece }\end{array}$} & 22 & 8 & 70 \\
\hline & 5 & 23 & 72 \\
\hline \multirow{2}{*}{$\begin{array}{l}\text { Literature, poetry and extract reading related to the } \\
\text { listened piece }\end{array}$} & 35 & 17 & 48 \\
\hline & 23 & 45 & 32 \\
\hline \multirow{2}{*}{$\begin{array}{l}\text { Discussion of the most important details of the } \\
\text { listened piano piece }\end{array}$} & 23 & 5 & 72 \\
\hline & 23 & 50 & 27 \\
\hline \multirow[t]{2}{*}{ Comparison of a few different music examples } & 27 & 7 & 66 \\
\hline & 5 & 50 & 45 \\
\hline \multirow{2}{*}{$\begin{array}{l}\text { 'Live’ piano playing of the fragments of a listened } \\
\text { piece }\end{array}$} & 32 & 3 & 65 \\
\hline & 9 & 50 & 41 \\
\hline \multirow[t]{2}{*}{ Learners’ discussions about the performed music } & 33 & 10 & 57 \\
\hline & 4 & 23 & 73 \\
\hline \multirow{2}{*}{$\begin{array}{l}\text { Learners' creative work related to the listened music } \\
\text { piece }\end{array}$} & 17 & 32 & 51 \\
\hline & 9 & 14 & 77 \\
\hline
\end{tabular}

${ }^{*}$ Chinese students ${ }^{* *}$ Lithuanian students

Table 2 presents the peculiarities of a music teacher's activity.

Table 2 shows that among the Chinese students, the statement "While selecting works for listening, I would take into account learners' wishes and requests" was the one they agreed with the most (it accounts for $58 \%$ ). It clearly shows that the Chinese participants of the survey were willing to take into account learners' interests, as well as to introduce the proposed ideas into the classroom, which might improve the efficiency of teaching. The statement that the Chinese students were most uncertain about was "All learners must start liking classical music", which accounts for $58 \%$. It points out a possible lack of experience in teaching as they were uncertain about the students' preferences. The Lithuanian 
Rauduvaite \& Li, 2018. Teacher's Music Activities in the Classroom as a Prerequisite for Improvement of Music Education

students mostly agreed among themselves. "If the learners are attentive and obedient during the lessons, they will learn the taught subject relatively well" was the answer that accounted for $77 \%$ in total. They found the necessity of learners' attentiveness and obedience during the lessons to be very important. On the other hand, $63 \%$ of them disagreed with the statement "I think that sometimes I could 'impose' my opinion on learners because they haven't formed their scale of values yet” - they respected the learners' right to express their opinion.

Table 2 Perspectives of teaching music in general schools (\%)

\begin{tabular}{|c|c|c|c|}
\hline Possibilities of improving music activities & $\begin{array}{l}\text { Definitely } \\
\text { yes }\end{array}$ & $\begin{array}{l}\text { I don't } \\
\text { know }\end{array}$ & $\begin{array}{l}\text { Definitely } \\
\text { no }\end{array}$ \\
\hline \multirow[t]{2}{*}{ I would like to work in a school as a music teacher. } & 47 & 32 & 21 \\
\hline & 50 & 41 & 9 \\
\hline \multirow{2}{*}{$\begin{array}{l}\text { If the learners are attentive and obedient during the } \\
\text { lessons, they will learn the taught subject relatively } \\
\text { well. }\end{array}$} & 53 & 32 & 15 \\
\hline & 77 & 18 & 5 \\
\hline \multirow{2}{*}{$\begin{array}{l}\text { I would stay faithful to my profession even having an } \\
\text { opportunity to switch to a better-paid job unrelated to } \\
\text { music. }\end{array}$} & 42 & 37 & 21 \\
\hline & 18 & 68 & 14 \\
\hline \multirow{2}{*}{$\begin{array}{l}\text { While selecting works for listening, I would take into } \\
\text { account learners' wishes and requests. }\end{array}$} & 58 & 30 & 12 \\
\hline & 73 & 14 & 14 \\
\hline \multirow{2}{*}{$\begin{array}{l}\text { Most frequently we sing songs which are not included } \\
\text { into the curriculum but are liked by learners. }\end{array}$} & 57 & 30 & 23 \\
\hline & 36 & 55 & 9 \\
\hline \multirow[t]{2}{*}{ All learners must start liking classical music. } & 12 & 58 & 30 \\
\hline & 18 & 23 & 59 \\
\hline \multirow{2}{*}{$\begin{array}{l}\text { I think that sometimes I could 'impose' my opinion } \\
\text { on learners because they haven't formed their scale of } \\
\text { values yet. }\end{array}$} & 37 & 52 & 11 \\
\hline & 5 & 32 & 63 \\
\hline
\end{tabular}

*Chinese students ${ }^{* *}$ Lithuanian students

All of the answers show that the participants of the survey would respect the learners' suggestions, which could enhance the performance of the teacher and the students.

While analysing the possibilities of improving music teachers' activity, the interview was used to reveal the priority types of music activity by the teachers. The teachers maintained the following:

- $\quad$ When I take my learners sing in chorus together, they are more active (a Chinese teacher).

- $\quad$ I prefer listening to music and singing. Introducing music by listening can attract learners' interests; singing can also help to learn new music pieces and recognize different styles (a Chinese teacher). 
- $\quad$ Singing is an activity which could combine rhythm, movement, solfeggio and other aspects in one, and it can be used under any conditions (a Lithuanian teacher).

- $\quad$ When I or the learners play an instrument they are more focused. First of all, I let the learners play by themselves before teaching. Singing and playing could inspire learners' creativity" (a Lithuanian teacher).

Moreover, the interview aimed at revealing the peculiarities of the most appropriate techniques employed in the music lessons for seventh-eighth grades. It is noteworthy that the applied methods do not always match the intended activity, learner needs and possibilities, and only partly help to reveal the individuality and creative power of every learner. Therefore, it is important that such learning methods which give freedom to learners' thoughts and activities, teach to respect friends' ideas, and promote an individual attitude are applied (General Curricular of Primary and Basic Education of Lithuania, 2009).

- I like to thoroughly analyse the knowledge of harmony, summed up by its features of structure to help students to understand the work better (a Chinese teacher).

- I like to combine singing with percussion in the class, which makes the learners more active (a Chinese teacher).

- Learners draw pictures while listening to music pieces; using body percussion and a cappella; creative music exercises and games (a Lithuanian teacher).

- $\quad$ I like the play a game which is called rondo: the teacher makes 1 rhythmic pattern, learners make 4 different rhythmic patterns, we continue to make patterns all across (a Lithuanian teacher).

Consequently, we find that the Chinese teachers like using instruments, while Lithuanian teachers like creativity activities the most. It verifies that different music activities can have an effect on the teachers' expression in teaching music. Both groups learn more forms of music activities. We can see that when the teacher joins the activities, he/she gradually gets more experience on how to apply music activities, which improve the quality of teaching. It is possible to claim that every teacher should discover such methods and techniques which would help him/her and his/her learners to attain the learning goals most efficiently.

During the interview, the teachers were asked if they agreed with the following idea: "Good emotions, good thoughts and music cognition are the most important things in nurturing listening to music". They teachers maintained the following:

- An important stage of elementary music education is establishing the 'beauty' of music, listening to music with good emotions and thoughts will be helpful (a Chinese teacher). 
Rauduvaite \& Li, 2018. Teacher's Music Activities in the Classroom as a Prerequisite for Improvement of Music Education

- $\quad$ Good or bad mood can influence whether learners are concentrated on the appreciation of the music pieces, and perceive the mood of the music piece more accurately (a Chinese teacher).

- $\quad$ Good interaction in the classroom cannot be achieved without good emotions (Lithuanian teacher).

- $\quad$ Good emotions, thoughts and cognition will also help the learners to stay disciplined, it is convenient for carrying out music activities (a Lithuanian teacher).

In the activities of teaching music, the teachers' positive emotions can have a certain impact on the students' emotional role, which can help learners to deal with difficulties, overcome them and develop their persistence ( $\mathrm{Wu}, 2007)$. The answers obviously show that the teachers agree with this viewpoint; they believe that good mood creates a good atmosphere to enjoy music; positive and progressive ideas can also drive learners' initiative to learn music. Good music awareness is also an important basis for solid music learning; thus it is highly necessary.

Defining the diversity of the expression of a music teacher in a lesson, attempts were made to distinguish the main activities that would involve playing music with the learners:

- $\quad$ Teachers should pay attention to the cooperation between the learners and the teachers, improve the learners' ability to express their opinion on music, and understand music on a deep and effective level (a Chinese teacher).

- $\quad$ I would like to use all of the activities (singing, playing, solfeggio, creative work and improvisation) in my class (a Chinese teacher).

- Using all music activities can improve the learning process from all aspects, keeping all musical abilities in balance is a good thing, ethnic music must be one of the teaching parts (a Lithuanian teacher).

- $\quad$ Teachers should pay attention to music expression, it will influence the way of thinking of all the learners (a Lithuanian teacher).

Thus, we conclude that the interviewees like music expression and prefer to learn all music activities. While Lithuanian teachers mostly prefer creativity exercises, both Lithuanian and Chinese teachers like using techniques related to listening to music and keeping balance in all music activities. According to Z. Rinkevičius (2002), it is important to apply all methods in music activity that provoke a learner to admire, to get amazed, to experience and contemplate, to critically evaluate, to personally recreate, as well as to prolong music fascination.

\section{Conclusions}

The review of scientific resources, which analyse the activity of a music teacher, enables to state that music education is important for the development of a child's personality. The analysed resources confirm that after evaluating urgent 
problems of age stages, which learners face in the seventh-eighth grades, the teacher's pedagogical contribution to music activities is perceived as a necessary condition for a smooth and successful music activity, which increases the motivational level in learning music. The learners of this specific age category are emotional and sensitive. They try to understand life through feelings. Therefore, the teacher's music activity can have an impact on teenagers by shaping their viewpoint on the sociocultural music environment.

The collected data of the recent investigation emphasise that all the types of music activities accompanied by a music teacher are linked to one common pedagogical process in general education schools, ensuring an even and comprehensive music education for learners. It should be noted that teachers ascribe different priorities for music activities depending on the chosen aims, methods, teaching tools and techniques. The research data reveal that music activities provide many opportunities for the seventh-eighth grade learners to experience the joy of musicianship. The types of music activities implemented with the teacher's cooperation and supervision are all equally necessary: listening to music, singing, playing, solfeggio, etc. Everything depends on how attractive and mesmerising the teacher's activity and ability to convey music by selfexpression (playing instruments, singing, etc.) are, which can evoke the students' positive emotions and create favourable conditions for musical activities in the classroom. Music education in such an environment is more attractive and successful, as it helps to solve personal and interpersonal issues (by applying various methods), which are natural for this specific age group of learners.

The teachers recognise the importance of music activities in general education schools and the significance of their active participation in music activities. Moreover, the data of the research reveal that the future music teachers do not have enough confidence and practical experience yet.

The analysis of the investigation seems to claim that music teachers in general education schools give priority to singing, playing and listening to music. According to the analysis of the lesson observation, the latter music activities serve as a helpful tool in creating musical interaction with the learners of the seventh-eighth grades. It can be assumed that the teachers' expression in musical activities serves as a peculiar mirror, according to which the learners gain knowledge of the music subject, as well as recognise themselves, others and the surrounding world.

In order for music education to be more effective in general education schools, an appropriate and favourable environment is necessary. According to the collected data, a variety of music activities helps to develop the learners' inborn musical abilities, provides a favourable learning environment with an opportunity to develop the learners' musicianship, as well as presupposes transferable skills. In this context, the teachers' active and creative music 
Rauduvaite \& Li, 2018. Teacher's Music Activities in the Classroom as a Prerequisite for Improvement of Music Education

involvement helps the learner to experience more positive emotions. Such a personal involvement and cooperation serve as a major condition for the improvement of the teacher's music activity. An inappropriate choice of the activities can lead to dissatisfaction and be the main reason for failure.

The research data also reveal that the teachers' personal involvement in music activities is extremely important for the learners of the seventh-eighth grades, meaning that the teachers' participation in music activities could encompass a number of music modes, which could create a more attractive and productive activity in a lesson: teacher - performer - listener - facilitator leader.

\section{References}

Balčytis, E. (2012). Muzikinio ugdymo labirintais (Labyrinths of Music Education). Šiauliai: ŠU leidykla.

Carvalho, S. H. M., \& Scavarda, A. (2014). Music Economy Field Configuration: An Exploratory Study. In D. Forrest (Ed.). Proceedings of the International Society for Music Education. 31st World Conference on Music Education, 210-215.

Juvonen, A., Ruismaki, H., \& Lehtonen, K. (2012). Music Education Facing New Challenges. Procedia-Social and Behavioral Sciences, 45, 197-205.

Liu, Y. (2012). The Position and Function of Listening to Music in Music Education. Northern Music, 11, 36-36.

Mantie, R. A (2013). Comparison of "Popular Music Pedagogy" Discourses. Journal of Research in Music Education, 61 (3), 334-352.

Mark, M., \& Madera, P. (2014). Contemporary Music Education. Schirmer: Cengage Learning.

Pradinio ir pagrindinio ugdymo bendrosios programos (General Curricula of Primary and Basic Education of Lithuania). (2009). Vilnius: Švietimo aprūpinimo centras.

Rauduvaite, A. (2016). Possibilities of Popular Music Application Enhancing Music Education in the Context of School Learners' Socialisation. In Gerd-Bodo von Carlsburg (Eds.). Strategies for Teacher Training: Concepts for Improving Skills and Quality of Teaching (pp. 619-632). Frankfurt am Main: Peter Lang.

Rinkevičius, Z. (2002). Muzikinis mastymas ir jo ugdymas mokykloje (Music Thinking and its Development at School). Klaipeda: Spindulys.

Strakšienè, D. (2009). Muzikos kūriniu didaktinès reflleksijos (Didactic Reflection on Music Works). Šiauliai: ŠU leidykla.

Wang, X. (2012). The Basic Elements of the Formation of Excellent Teaching Style of Music Teachers. Education Research Forum, 131 (11), 82-83.

Wu, S. (2007). The Significance of Emotional Experiences in Music Appreciation. Journal of Music Education, 12, 12-12.

Yang, Y. (2013). Teaching Methods, Learning Well-founded - a study of 2012 people publishing house textbook. China Music Education, 12, 29-31.

Zhao, X. (2015). How Instrumental Music Teaching Enters Middle School Classroom. Journal of Seeking Knowledge Guide, 13 (1), 144-145.

Žydžiūnaitè, V., \& Sabaliauskas, S. (2017). Kokybiniai tyrimai (Qualitative Research). Vilnius: Vaga. 